\title{
PERANAN TPI(TEMPAT PELELENGAN IKAN) PONRANG DALAM MENINGKATKAN PENDAPATAN MASYARAKAT SETEMPAT (STUDI KASUS DI DESA TIROWALI KECEMATAN PONRANG)
}

\author{
NURLINDA,SAHARRUDDIN
}

\begin{abstract}
ABSTRAK
Pengelolaan sumber daya wilayah pesisir dan lautan di Indonesia dari sudut pandang pembangunan berkelanjutan (sustainable development) dihadapkan pada kondisi yang bersifat mendua atau berada di persimpangan jalan. Pada umumnya para nelayan masih mengalami keterbatasan tekhnologi penangkapan sehingga wilayah operasi pun menjadi terbatas, hanya diseekitar perairan pantai.Selain masalah produksi, maka masalah pemasaran juga dihadpi dari nelayan.Untuk membantu memasarkan hasil tangkapan nelayan maka dibangunlah tempat pelelangan ikan (TPI). Tempat pelelangan ikan (TPI) merupakan pungsi utama dalam kegiatan perikanan dan juga merupakan salah satu factor yang menggerakkan dan meningkatkan usaha dan kesejahtraan nelayan.

Penelitian tentang Peranan TPI (Tempat Pelelengan Ikan) Ponrang Dalam Meningkatkan Pendapatan Masyarakat Setempat Studi Kasus Di Desa Tirowali Kecematan Ponrang bertujuan untuk mengetahui bagaimana peranan TPI ponrang dalam meningkatkan pendapatan masyarakat setempat jika dihubungkan dengan Efisiensi Harga dan Efektivitas (waktu jangkau transportasi).

Adapun metode analisis yang digunakan adalah uji analisis regresi yang mencakup uji korelasi, regresi linear berganda digunakan untuk mengetahui pengaruh keberadaan TPI Ponrang dalam meningkatkan pendapatan masyarakat sekitar, serta analisis varians menggunakan uji-F dan uji-T.

Dari hasil penelitian menunjukkan bahwa Variable Efisiensi Harga (X1) dan Efektivitas (waktu jangkau transportasi) (X2) secara serempak berpengaruh singnifikan terhadap pendapatan (Y) masyarakat di TPI (Tempat Pelelangan Ikan) ponrang desa tirowali serta menunjukkan bahwa Variable Efisiensi Harga (X1) dan Efektivitas (waktu jangkau transportasi) (X2) secara parsial berpengaruh singnifikan terhadap pendapatan (Y) masyarakat di TPI (Tempat Pelelangan Ikan) ponrang desa tirowali.
\end{abstract}

Kata kunci: Tempat Pelelangan Ikan, efisiensi harga, efektivitas (waktu jangkau tarnsportasi), pendapatan masyarakat. 


\section{Pendahuluan}

\section{Latar belakang}

Kelautan dan perikanan dalam konstalasi pembangunan ekonomi Indonesia kini mendapat perhatian serius.Sejak reformasi 1998, pemerintah Indonesia membentuk depetemen eksplorasi laut dan perikanan (DELP), lalu berubah depertemen kelautan dan perikanan (DKP) hingga kementrian kelautan dan perikanan (KKP). Bahkan, pada aera pemerintahan K,H,Abdurahman Wahid (Gus dur), ia mengangkat laksamana Widodo, AS sebagai panglima TNI secara ekonomi politi, Gus Dur telah memposisikan kelautan dan perikanan sebagai kekuatan politik baru dalam pembangunan nasional (Apridar, dkk, $2011: 1$ )

Pengelolaan sumber daya wilayah pesisir dan lautan di Indonesia dari sudut pandang pembangunan berkelanjutan (sustainable development) dihadapkan pada kondisi yang bersifat mendua atau berada di persimpangan jalan (Dahuri dkk, dalam mulyadi S.,2007:V111). Ada banyak kawasan yang belum sama sekali tersentuh oleh aktifitas pembangunan, namun dipihak lain terdapat beberapa kawasan pesisir yang telah dimanfaatkan (dikembangkan) dengan insentif. Akibatnya, terlihat indikasi telah terlampauinya daya dukung atau kapasitas berkelanjutan (potensi lestari) dari ekosistem pesisir dan lautan, seperti penemaran, tangkap lebih (over fishing), degradasi fisik habitat pesisir, dan abrasi pantai, telah muncul di kawasan-kawasan pesisir. Fenomena ini telah ada dan masih berlangsung, terutama di kawasankawasan pesisir yang padat penduduknya dan tinggi tingkat pembangunannya, seperti selat malaka, pantai utara jawa, bali, Lombok, NTT, dan Sulawesi selatan.

Pada umumnya para nelayan masih mengalami keterbatasan tekhnologi penangkapan sehingga wilayah operasi pun menjadi terbatas, hanya diseekitar perairan pantai.Selain masalah produksi, maka masalah pemasaran juga dihadpi dari nelayan.Untuk membantu memasarkan hasil tangkapan nelayan maka dibangunlah tempat pelelangan ikan (TPI). Tempat pelelangan ikan (TPI) merupakan pungsi utama dalam kegiatan perikanan dan juga merupakan salah satu factor yang menggerakkan dan meningkatkan usaha dan kesejahtraan nelayan (wiyono, dalam pramitasari S. D.,dkk,2006 :13). Dalam banyak masyarakat nelayan di berbagai tempat, nelayan dan pedagang perantar (tengkulak) terikat oleh hubungan kerja sama yang kuat demi kepentingan jangka panjang. Hubungan kerjasama tersebut bertujuan untuk mengatasi kesulitan nelayan dalam memasarkan hasil tangkapan yang kualitasnya cepat menurun dank arena keterbatasan modal usaha. Disisi lain, nelayan selalu dirugikan dalam hubungan kerjasama tersebut (Acheson dalam kusnadi, 2000 :112). Tapi dengan adanya TPI secara tidak langsung mengurangi fungsi dari para tengkulak tadi sehingga kerugian para nelayan berkurang yang tentu saja akan mempengaruhi tingkat pendapatan dan kesejahtraan nelayan. Masalah dalam penelitian ini adalah Bagaiman peranan TPI ponrang dalamdalam meningkatkan pendapatan asyarakat setempat?. Tujuan penelitian ini adalah Untuk mengetahui 
bagaimana peranan TPI ponrang dalam meningkatkan pendapatan masyarakat setempat.

\section{Metode Penelitian}

Lokasi dan waktu penelitian

Penelitian skripsi ini akan dilaksanakan di TPI ponrang di desa tiro wali kecematan ponrang. Jangka waktu penelitian ini sekitar enam bulan, dari tahap persiapan awal sebelum penelitian sampai dengan tahap penyelesaian penelitian.Penetapan lokasi penelitian ini dilakukan secara sengaja atas dasar pertimbangan agar mempermudah penelitian dalam memperoleh data.

Jenis dan sumber Data

Pada penelitian ini jenis data yang digunakan adalah data primer dan data sekunder.Data primer adalah data yang diperoleh dengan melakukan wawancara secara langsung dari responden baik itu berupa koisioner maupun angket.Sedangkan data sekunder, diperoleh dari perpustakaan maupun literature yang berkaitan dengan penelitian.

Populasi dan sampel

Populasi adalah keseluruhan subjek penelitian yang menjadi perhatian pengamatan dan penyediaan data. Populasi pada penelitian ini adalah seluruh masyarakat desa tiro wali yaitu sebanyak 588 kepala keluarga.Sampel adalah sebagian atau wakil populasi yang diteliti (arikunto, 2006:131).Agar hasil penelitian dapat digeneralisasikan kepada populasi, sampel yang diambil harus bersifat representative, artinya sampel harus mencerminkan dan bersifat mewakili keadaan populasi.

Metode pengumpulan data

Observasi sebagai tekhnik pengumpulan data mempunyai ciri yang spesifik bila dibandingkan dengan tekhnik yang lain, yaitu wawancara dan koisioner, selalu berkomunikasi dengan orang, maka observasi tidak terbatas pada orang, tetapi juga obyek-obyek alam yang lain (sugiyono, 2011:145). Sebelum mengadakan penelitian dilapangan peneliti melakukan observasi awal kelokasi penelitian dan juga kepada masyarakat untuk mengetahui sejauh mana sejauh mana pengetahuan responden terhadap obyek yang akan di teliti.

Wawancara digunakan sebagai tekhnik pengumpulan data apabila peneliti ingin melakukan studi pendahuluan untuk menemukan permasalahan yang harus diteliti, dan juga apabila peneliti ingin mengetahui hal-hal dari responden yang lebih mendalam dan jumlah respondennya lebih sedikit (sugiyono, 2011:142). 
Tahap pengumpulan data primer dengan menggunakan metode angket atau kuisioner yang dilakukan dengan cara memberi sejumlah pertanyaan pada responden atau pihak-pihak yang bersankutan dengan masalah yang akan diteliti.

\section{Metode Analisis Data}

Analisis data dilalakukan dengan berorientasi kepada masalah dan tujuan penelitian, untuk mencapai tujuan penelitian digunakan uji analisis regresi yang mencakup uji korelasi, regresi linearberganda, serta analisis varians menggunakan uji-F dan uji-T.

1. Analisis regresi

2. Analisis regresi linear berganda

Metode analisis linear berganda digunakan untuk mengetahui pengaruh keberadaan TPI Ponrang dalam meningkatkan pendapatan masyarakat sekitar.

\section{Hasil Penelitian Dan Permasalahan}

Gambaran umum lokasi penelitian

Ponrang secara administratif merupakan ibu kota desa Tirowali, kecematan Ponrang, kabupaten Luwu. Secara geografis terletak dan diapit oleh desa Mario di sebelah barat, desa buntu kamiri disebelah timur, desa tanjung disebelah selatan, dan teluk bone disebelah selatan.Secara astronomis ponrang terletak pada koordinat $119^{\circ} 2.4 .17^{\circ} 30 \mathrm{BT}$ dan $5^{\circ} 8.18 \mathrm{LS}$. yang memungkinkan daerah iniberiklim tropis.

Secara administrative desa tiro wali terdiri atas 3 (tiga) dusun yaitu: dusun ponrang, dusun lumi, dan dusun mappideceng. Dusun ponrang berada di wilyayah bagian barat, lumi di bagian timur, dan mappideceng terhampar memanjang mengikuti alur teluk bone di sebelah utara.

Daerah ini dilaluai oleh sungai ponrag yang mengalir sepanjang 20 kilometer dari hulu sungai di sebelah barat desa Tampa dan bermuara ke teluk bone yang salah satunya memberiadil yang cukup besar dalam transportasi laut sebagai potensi bidang perikanan. Desa ini mempunyai peluang untuk mengembangkan pengelolaan hasi usaha penangkapan ikan laut, pemeliharaan ikan tambak dan budidaya udang windu.Ketiga komoditi tersebut merupakan komoditas andalan disektor perikanan di daerah ini.Hal itulah yang mendorong keberadaantempat pelelangan ikan (TPI) di ponrang.

Desa tirowali merupakan desa pesisir yang keadaan wilayahnya adalah dataran rendah (ketinggian tanah dari permukaan laut $3 \mathrm{~m}$ ) dengan hamparan seluas 1.500 ha. Bagian selatanwilayahnya adalah hamparan tanah persawahan an sebagian kecil disebelah timur. Sementara disebelah barat adalah tanah perkebunan cokelat.Sedangkan disebelah timur membujur dari selatan batas sebelah selatan (desa Bt. Kamiri) sampai kebatas utara (desa Mario) mengikuti alur pantai teluk bone, adalah lokasi tambak yang potensial. 
Desa tirowali termasuk daerah yang berikli tropis, karena letaknya berdekatan dengan garis katulistiwa. Kelembaban udara berkisar antara 62\%, sedangkan curah hujan tahunan rata-rata $221 \mathrm{~mm}$ dengan jumlah hari hujan berkisar 123 hari pertahun. Sedangkan temperature/suhu udara rata-ratadi desa tiro wali sekitar $27^{\circ} \mathrm{C}$.

Setiap jumlah penduduk desa Tirowali mengalami perubahan.Perubahan tersebut tidak hanya disebabkan oleh tingkat kelahiran dan kematian, tetapi juga disebabkan oleh migrasi penduduk.Ketiga factor tersebut merupakan factor utama perubahan jumlah penduduk.

Pertumbuhan penduduk yang tinggimerupakan potensi pembangunan, dan lapangan kerja. Akan tetapi manakala hal tersebut tidak terpenuhi, maka akibatnya pertumbuhan penduduk yang tinggi akan menimbulkan masalah, diantaranya terjadi pengangguran.

Untuk itu perlukanperencanaan yang matang dalam pengendalian penduduk yang nantinya biasa memainkan peranan yang penting dalam hal mengatasi ketegangan dan gejolak social di masyarakat.

Berikut adalah jumlah pertumbuhan penduduk tirowali dalam kurun waktu lima tahun waktu (2007-2011) disajikan dalam table dibawah ini. Table 4.1.jumlah penduduk desa tirowali dan pertumbuhannya dalam kurun waktu 5 tahun (20072011)

\begin{tabular}{|l|l|l|l|}
\hline No. & Tahun & $\begin{array}{l}\text { Jumlah penduduk } \\
\text { (Jiwa) }\end{array}$ & $\begin{array}{l}\text { Laju pertumbuhan } \\
\text { Pertahun (\%) }\end{array}$ \\
\hline 1 & 2007 & 4.094 & - \\
\hline 2 & 2008 & 4.286 & 9,16 \\
\hline 3 & 2009 & 4.562 & 12,29 \\
\hline 4 & 2010 & 4.936 & 14,60 \\
\hline 5 & 2011 & 5.591 & 22,31 \\
\hline
\end{tabular}

Sumber Data:kantor kepala desa tirowali,2012

Dari table diatas dapat dijelaskan bahwa laju pertumbuhan penduduk desa tirowali mengalami peningkatan dari tahun ketahun.Hal ini dapat dilihat persentase laju pertumbuhan. Pada tahun 2007-2008 sebesar 9,16\%, tahun 2009 sebesar 12,29\%, tahun 2010 sebesar 14,60\%, dan pada tahun 2011 mengalami peningkatan yang signifikan sebesar 22,31\%.

Bedasarkan pada laju pertumbuhan tersebut, pertambahan penduduk juga bervariasi dari tahun ketahun. Pada tahun 2007-2008 bertambah sebanyak 192 jiwa, tahun2008-2009 bertambah 280 jiwa, dari tahun 2009-2010 mengalami penambahan sebanyak 374 jiwa dan pada tahun 2010-2011 sebesr 655 jiwa. Penambahan tersebut bila dijumlah keseluruhan dalam kurun waktu tersebut bertambah sebanyak 1.501 jiwa yang apabila dirata-ratakan setiap tahunnya, adalah sebesar 375 jiwa/tahun atau 14,59\%. Hingga saatini jumlah kepala keluarga yang ada di desa tirowali adalah 588 kepala keluarga. 


\section{Penutup}

Kesimpulan penelitian ini adalah: (a) Variable Efisiensi Harga (X1) dan Efektivitas (waktu jangkau transportasi) (X2) secara serempak berpengaruh singnifikan terhadap pendapatan (Y) masyarakat di TPI (Tempat Pelelangan Ikan) ponrang desa tirowali., (b) Variable Efisiensi Harga (X1) dan Efektivitas (waktu jangkau transportasi) (X2) secara parsial berpengaruh singnifikan terhadap pendapatan (Y) masyarakat di TPI (Tempat Pelelangan Ikan) ponrang desa tirowali. Adapun Saran dari penelitian ini adalah: (a) Efesiensi harga dfektivitas (waktu jangkau transportasi) dapat dijadikan prioritas utama bagi pemerintah desa tirowali kecematan ponrang khususnya pengawas di TPI (Tempat Pelelangan Ikan) sebagai acuan untuk meningkatkan kinerja dan pelayanannya dalam rangka meningkatkan pendapatan masyarakat, (b) Bagi peneliti selanjutnya, apabila ingin meneliti pendapatan masyarakat hendaknya meneliti factor-faktor lain yang belum di teliti dalam penelitian ini untuk memperluas pengetahuan masyarakat.

\section{Daftar Pustaka}

Anggara, $\quad \mathrm{H}$ 2010.Pengertian masyarakat.Artikel (http://harrisanggara.Blogspot.com/2010/11/pengertian masyarakat.html), diaskes 18 november 2011).

Apridar, Karim, M.,dan suhana. 2011. Ekonomi kelautan pesisir. Yogyakarta:Graha Ilmu.

Aswar.2011. pengaruh tayangan iklan Gery chocolatos di televise terhadapkeputusan membeli coklat pada mahasiswa politekhnik Negeri Jember. Tugas akhir.Jember :D4 Manajemen Agribisnis politeknik Negeri Jember.

Badan pusat statistic kabupaten Luwu. 2010. Kecematan ponrang dalam angka 2009. Luwu. Pemda Kabupaten Luwu.

Bunga.A.S. 2004.Kontribusi Retribusi TempatPelelangan Ikan (TPI) ponrang terhadap penerimaan pendapatan Asli Daerah (PAD) Kabupaten Luwu.Skripsi.Palopo : Fakultas Ekonomi Universitas Andi Djemmah. 